\title{
Adoption of FRS 138 and Audit Delay in Malaysia
}

\author{
Najihah MarhaYaacob (Corresponding author) \\ Faculty of Accountancy, Universiti Teknologi MARA Terengganu \\ 23000 Dungun, Terengganu Malaysia \\ Tel: 60-9-845-8489Ｅ-mail: najihahm@tganu.uitm.edu.my
}

\author{
Ayoib Che-Ahmad \\ College of Business, Universiti Utara Malaysia \\ 06010 UUM Sintok, Kedah Malaysia
}

Tel: 60-4-928-3942Ｅ-mail: ayoib@uum.edu.my

Received: March 29, 2011

Accepted: May 6, 2011

Published: January 1, 2012

doi:10.5539/ijef.v4n1p167

URL: http://dx.doi.org/10.5539/ijef.v4n1p167

This research is financed by the Ministry of Higher Education, Malaysia

\begin{abstract}
In respect of the International Financial Reporting Standards (IFRS) convergence, auditing works have become too complicated in the way auditors are burdened with so many changes of standards. The complexity of IFRS adoption is mainly attributable to certain standards that have received considerable criticism from the preparers and the auditors due to their ambiguous measurement and recognition. As FRS 138 is a new IFRS in Malaysia, and the accounting treatment for intangible assets are the most controversial and complex issue in the financial reporting field (Lhaopadchan, 2010), there is a question of whether FRS 138 adoption in Malaysia would affect audit efficiency. Hence, this study aims to examine the relationship between the adoption of FRS 138 on the timely issuance of audit report. The final sample consists of 2,440 firm-year observations. The panel regression analysis reveals a significant positive relationship between FRS 138 adoption and audit delay. The result proves that FRS 138 is a complex standard that takes the auditor more time to audit.
\end{abstract}

Keywords: Audit delay, Malaysia, FRS 138, Panel Data Analysis, Fixed Effects Model

\section{Introduction}

The transition to an international single accounting standard, namely, the International Financial Reporting Standards (IFRS) is regarded as a big transformation to some countries. The issue of IFRS complexity has become a major concern among the preparers of financial statements, directors and auditors. Since the new IFRS requires increased disclosure, it demands more time and effort to extensively verify and provide assurance on the audited financial statements (Hoogendoorn, 2006). Moreover, as the core attribute of IFRS is fair value accounting (Lhaopadchan, 2010), the concern has grown immeasurably as the management has to exercise greater judgment in IFRS environment. The complexity of IFRS adoption is mainly attributable to certain standards that have received considerable criticism from the preparers and the auditors due to their ambiguous measurement and recognition. For instance, accounting debates on the definition, measurement and recognition (Tollington, 2008; Gallego and Rodriguez, 2005; Grasenik and Low, 2004) of intangible assets are a never-ending story and the accounting treatment for intangible assets are labelled as "one of the most controversial and intractable issues in accounting" (Lhaopadchan, 2010 p.123). Although it has been discussed in the literature for over a century, there is no consensus on the true meaning of intangible assets and how they should be accounted and reported. Even with the availability of IFRS 138 on Intangible Assets, conflicting opinions linger, especially concerning the complexity of recognition (Tollington, 2008).

In Malaysia, public listed companies have also been exposed to a major challenge due to the adoption of 21 IFRS by the Malaysian Accounting Standards Board (MASB), beginning 1 January 2006. (Note 1)This has resulted from the MASB's attempt to move Malaysia closer to the global convergence of accounting standards. Thus, many parties are in doubt as to whether all Malaysian IFRSs could be applied due to the complexity and vagueness of several standards, especially the new IFRS such as FRS 138 (Note 2) and FRS 139. As Schadewitz and Vieru (2010) 
asserted, the problem of complexity and lack of companies' preparation increase the risk in audit assignment and the problem becomes more serious for the newly introduced standards.

\section{Audit Delay}

Audit timeliness is a reflection of the number of hours required to perform the tasks that are influenced by the amount of interim audit work performed, the number of auditors assigned to the engagement and the number of extra hours needed (Lawrence and Glover, 1998). Audit timeliness is usually linked to the audit efficiency, which measures how competent the auditors are in performing their duty to arrive at an audit opinion that represents the true picture of a company's operation. Information that reaches the investors diminishes when there is an increase in reporting lag, as timely disclosure of accounting information in the annual report plays an important role in order to reduce information asymmetry between the preparers and the users of financial statements. The regulatory bodies and researchers are giving more attention to the issue of timeliness (Knechel and Payne, 2001) and they regard it as the most influential factor to assess the quality of financial statements (Owusu-Ansah, 2000). According to Leventis, Weetman and Caramanis (2005), the timeliness of audit report is an important aspect in emerging markets since investors have no other reliable choice of information other than the audited annual report. In Malaysia, Chapter Two and Chapter Nine of the Bursa Malaysia Listing Requirements demand for a timely issuance of financial reporting.

The issue of audit report timeliness has been investigated for the past 30 years. The evidence documented from the data of different countries, includes developed countries like the US (Ashton, Willingham and Elliot, 1987), New Zealand (Carslaw and Kaplan, 1991), Hong Kong (Jaggi and Tsui, 1999), Canada (Ashton, Graul and Newton, 1989), France (Soltani, 2002), Australia (Dyer and McHugh, 1975), the UK (Abdelsalam and Street, 2007), Spain (Bonsón-Ponte, Escobar-Rodríguez and Borrero-Domínguez, 2008) as well as developing countries such as Zimbabwe (Owusu-Ansah, 2000), Bangladesh (Iman, Ahmed and Khan, 2001), Bahrain (Khasharmeh and Aljifri, 2010), Egypt (Ezat and El-Masry, 2008; Afify, 2009), Malaysia (Che-Ahmad and Abidin, 2008) and the United Arab Emirates (Khasharmeh and Aljifri, 2010). Studies on audit timeliness are frequently centred to ascertain the determinants of the audit report lag. Most of these researches contribute to the audit timeliness issue in public companies of the respective countries and the majority of them have utilized publicly available data.

Several factors have been identified in the literature that are associated with audit delay. During the earlier years, the most common factors were client size, client financial performance, client complexity, qualified opinion, debt structure and type of industry (Dyer and McHugh, 1975; Ashton et al., 1987). From further investigation it was ascertained that other determinants and studies revealed that ownership of companies, less experienced staff, incremental audit effort, audit technology, auditor's international link (Newton and Ashton, 1989; Bamber, Bamber and Schoderbek, 1993; Jaggi and Tsui, 1999) and corporate governance attributes (Abdullah, 2007; Ezat and El-Masry, 2008) were also contributory factors that influence the ability of auditors to undertake the timely issue of the audit report.

Almosa and Alabbas (2007) segregated all these factors into two (2) categories, namely, the company's attributes and auditor's attributes (Owusu-Ansah, 2000). In this study, a company's attributes consist of total assets, debt structure, sign of income, number of subsidiaries, audit opinion, accounting year-end, industry effect and corporate governance indicators. The type of auditor is a variable under auditor's attributes.

Total assets are most frequently used to measure size (Ashton et al., 1989; Newton and Ashton, 1989). Larger companies have more power to pressure auditors so that the audit can be completed in a timely manner (Carslaw and Kaplan, 1991). The majority of the previous studies have proven a negative association between the size of a company and audit delay (Davies and Whitted, 1980).

Leverage represents the extent of debt utilization in the company as compared to the total investment in assets. The high proportion of total debts exposes the company to the risk of default and, consequently, to the risk of bankruptcy. Al-Ajmi (2008), and Khasharmeh and Aljifri (2010) revealed a significant positive association between debt proportion ratio and audit timeliness. Ashton et al. (1989) stated that the sign of reported income differentiates between good news and bad news resulting from one-year's operation of the company. The bad news causes auditors to delay releasing the information (Carslaw and Kaplan, 1991). The literature has documented a significant association between audit delay and weak financial condition (Ashton et al., 1989; Bamber et al. 1993; Jaggi and Tsui, 1999; Afify, 2009). A large number of subsidiaries, particularly when they are located in diverse geographical areas, makes it more complex and difficult for the audit works to be carried out by the auditors. In Malaysia, Che-Ahmad and Abidin (2008) revealed that the number of subsidiaries significantly affects audit delay with a positive relationship. A qualified opinion is regarded as bad news and the company tends to delay the audit report so that investors' decision is not influenced by the negative news (Wang, Gu and Chen, 2008). Whittred (1980) 
suggested that the more serious the qualification, the longer the audit lag, because of the client-auditor negotiation and the extra time required to audit transactions as well as protect from litigation risks.

Many studies have employed accounting year-end to ascertain whether audit work conducted within the busy season is significant in explaining audit delay. Knechel and Payne (2001), Dyer and McHugh (1975), and Payne and Jensen (2002) did reveal that longer delays are experienced by busy season audits. Leventis et al. (2005) revealed that audit report lag was significantly shorter for Greek companies with big international audit firms and Khasharmeh and Aljifri (2010) discovered that international auditing firms in the United Arab Emirates reduced the audit delay. Different industries normally have different levels of audit difficulties and unique audit risk assessments. Bamber et al. (1993) claimed that the complexity of audit depends on the client's industry and, thus, affects the extent of audit work attached to the audit engagement.

The function of audit timeliness to measure the quality of financial statements has motivated a few studies to examine the influence of corporate governance attributes to audit efficiency. Givoly and Palmon (1982) stress that the management has some power to exercise their own judgment, such as the tendency to delay the issuance of the audit report in the case of any bad news. Thus, the independent management is perceived to alleviate the opportunistic behaviour by the board of directors. For this reason, previous studies, such as Abdelsalam and El-Masri (2008), Abdullah (2007) and Afify (2009), examined the impact of the proportion of non-executive directors on the board and audit timeliness. Moreover, the dual roles of the Chief Executive Officer (CEO) and the board chairman would limit the board's functions to assess the effectiveness of the CEO in managing the day-to-day operations of the company (Bliss, Muniandy and Majid, 2007). Past studies have shown mixed findings for the duality role variable (See for instance: Abdelsalam and El-Masri, 2008; Afify, 2009). The blockholders ownership as a measurement for the company ownership structure is perceived to be dominant in reducing the agency conflict between the agents and the principals, which, in turn, reduces the monitoring costs of the agent. Abdelsalam and El-Masry (2008) revealed that a higher percentage of blockholders outstanding shares significantly reduced audit timeliness.

\section{Intangible Assets}

The issue of intangibles has been the subject of great debate among the academicians in scholarly research. Egginton (1990, p. 193) claims that, "accounting for intangible assets is one (1) of the most intractable problems of financial reporting". Similarly, Lhaopadchan (2010) believes that the value of intangibles is the most difficult to determine. Concerning the definition of intangibles and whether they should be capitalized or expensed, the academic community normally argues about what is the right basis for amortization and where should intangibles be presented in the balance sheet. Canibano, Garcia-Ayuso and Sanchez (2000) argued that the only way to encounter the questions is by finding the generally accepted definition of intangible assets and liabilities. Traditionally, intangible assets were always allied to goodwill and recognized as the difference between the cost to acquire the enterprise and the fair value of net tangible assets. Goodwill arises when there is a purchase price premium over the net assets due to the brand name, good reputation and superior linkage between the customers and the suppliers.

Currently, while many studies provide a wide range of elements to determine the value of intangibles in the company, they fail to fit the definitions and do not match with the recognition criterion of intangibles. Due to there being no acceptable definition, the classification remains unresolved. Grasenik and Low (2004) pointed out that the lack of consensus concerning the definition and classification of intangibles is due to the dissimilar boundaries and perspectives of different interest groups concerning the purpose of an organization's assets. Hendriksen and Van Breda (1992) suggest that intangibles might be classified into two (2) categories: (i) traditional intangibles, which include goodwill, brand names and patents, and (ii) deferred charges like advertising, research and development and training costs. Kaufmann and Schneider (2004) stressed the importance of developing a comprehensive classification of intangibles so that managers can structure the intangible approaches within the organizations.

The most crucial debates on intangibles concern the recognition and measurement in the financial statements. Canibano et al. (2000) noted that there are two (2) traditional approaches to value goodwill, the valuation approach and the transactions approach. The valuation approach is based on the balance sheet while the transactions approach relies on the income statements. The main argument in recognizing intangibles is the issue of uncertainty in determining future economic benefits and to what extent intangibles are under the firm's control. Due to the uncertainty, some intangibles, such as training costs, might not be capitalized when a contractual relationship between the firms and employees cannot be established. There are two (2) different views on the way intangibles should be accounted. On the one hand, academicians argue that since intangibles are assets, they should be treated and recognized as other tangible assets (Lev and Zarowin, 1999), while on the other hand, other supporters claim 
that intangibles cannot be treated like tangibles since the value is not separable, there are no alternative uses and the recoverable amount is subject to uncertainty.

Prior to IFRS convergence, there were many treatments across different countries that hindered the harmonization of financial statements. In 1975, the FASB in the US required companies to expense the full Research \& Development (R\&D) costs as there is no direct relationship between $R \& D$ costs and definite future benefits derived from the outlays. From the advocates' point of view, this treatment reduces the chances for the managers to capitalize development costs, which do not give better prospects in the future (Healy, Myers and Howe, 2002). In 1998, International Accounting Standards Committee (IASC) issued IAS 38, which classified R\&D as an internally generated intangible asset and required full written off expense costs to income statements, and certain development costs were treated as assets to be capitalized over the period of 20 years. In contrast, the Australian Accounting Standards Board exposure draft 49, permits amortization of identifiable intangible assets over the period assets might reasonably expect to provide benefits. Similarly, the IV Directive of the European Union (EU) allows for capitalization of R\&D costs without detailing the criteria for recognition (Canibano et al., 2000). Evidently, the different methods used by different national standards may hamper comparability, which motivated the IASC to have a universal standard.

From the arguments before, the literature has shown the complexity of the work in the area of intangibles, from the definition and classification to the recognition and measurements (Bohusova and Svoboda, 2010). It is expected that the higher complexity and ambiguous treatment will cause auditors to spend more time in tracing audit evidence, which, subsequently, will delay the audit report. Thus, the hypothesis is:

$\mathrm{H}$ : there is a positive association between FRS 138 adoption and audit delay.

\section{Research Design}

The data in this study consist of publicly available information that was mainly obtained from the annual reports of the companies listed on the main board and the second board of Bursa Malaysia. The annual reports were downloaded from the Bursa Malaysia Company Announcement Webpage. All financial data and non-financial data were hand-collected from Bursa Malaysia annual reports. The final sample for this study consists of 2,440 company-year observations covering the period of four (4) years from 2005 to 2008 . From the total final sample, 1,768 observations were from the main board and 672 observations were from the second board of Bursa Malaysia.

The hypothesis variable, FRS 138 represents the dichotomous variable indicating ' 1 ' for the adoption of FRS 138, and ' 0 ' for non-adoption of FRS 138. The variable is obtained from the notes to accounts under the 'Basis of Preparation' section. The hypothesis of the study was tested based on the modified audit delay model originated from Ashton et al. (1989).

$$
\begin{aligned}
\operatorname{lnDELAY}_{\mathrm{it}}=\quad & \alpha+\beta_{1} \text { FRS138 }_{\mathrm{it}}+\beta_{2} \operatorname{lnSIZE}_{\mathrm{it}}+\beta_{3} \text { DEBT }_{\mathrm{it}}+\beta_{4} \text { LOSS }_{\mathrm{it}}+\beta_{5} \text { QUALIFIED }_{\mathrm{it}}+ \\
& \beta_{6} \text { SQSUBS }_{\mathrm{it}}+\beta_{7} \text { YEND }_{\mathrm{it}}+\beta_{8} \mathrm{BIG}_{\mathrm{it}}+\beta_{9} \text { INDUST }_{\mathrm{it}}+\beta_{10} \text { BDIND }_{\mathrm{it}}+\beta_{11} \text { DUAL }_{\mathrm{it}}+\beta_{12} \text { BLOCK }_{\mathrm{it}}+\mathrm{a}_{\mathrm{i}}+ \\
& \mathrm{u}_{\mathrm{it}}
\end{aligned}
$$

\begin{tabular}{|c|c|c|}
\hline Variables & $\begin{array}{l}\text { Exp. } \\
\text { Sign }\end{array}$ & Description \\
\hline $\operatorname{lnDELAY}$ & & $\begin{array}{l}\text { natural log of the length of time between the company's financial year-end and the } \\
\text { date of auditor's report }\end{array}$ \\
\hline$\alpha$ & & an intercept term, a constant \\
\hline$\beta$ & & a regression slope coefficient \\
\hline FRS 138 & + & FRS 138 adoption (code 1 if FRS 138 was adopted, 0 otherwise) \\
\hline $\operatorname{lnSIZE}$ & - & natural $\log$ of total assets \\
\hline DEBT & + & ratio of total debts to total assets \\
\hline LOSS & + & current year income (code 1 if company suffering losses, 0 otherwise) \\
\hline QUALIFIED & + & audit opinion (code 1 if the company received going concern opinion, 0 otherwise) \\
\hline SQSUBS & + & square root of the number of subsidiaries operated by clients \\
\hline YEND & + & month fiscal year end (code 1 if the company fiscal year end in between 31 \\
\hline
\end{tabular}

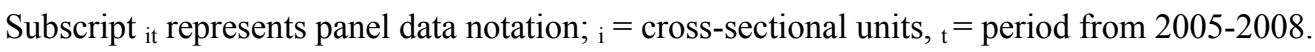

Where: 


\begin{tabular}{|c|c|c|}
\hline & & December until 31 March, 0 otherwise) \\
\hline BIG4 & - & firm's auditor (code 1 if client audited by Big 4, 0 otherwise) \\
\hline INDUST & + & $\begin{array}{l}\text { industry effect (code } 1 \text { if the company is under technology, consumer and } \\
\text { construction industry, } 0 \text { otherwise) }\end{array}$ \\
\hline BDIND & - & proportion of independent directors on the board \\
\hline DUAL & $?$ & CEO duality (code 1 if CEO is also chairman of the board, 0 otherwise) \\
\hline BLOCK & - & percentage of shares owned by independent block holders ( $>5 \%$ shares) \\
\hline$a_{i}$ & & unobserved company level effect \\
\hline$u_{i t}$ & & disturbance term \\
\hline
\end{tabular}

In this study, the panel data regression analysis was used in order to provide a richer interpretation and powerful understanding of the effect of FRS 138 adoption on audit delay. Panel data analysis mitigates the problem of omitted variables bias by capturing the unobserved effect and mitigates heterogeneity bias (Baltagi, 2005). Chou and Lee (2003) stress that panel data provides more concise and powerful conclusions concerning the relationship between the dependent and their independent variables.

The Breush Pagan Lagrangian Multiplier (LM) test for random effects was conducted to determine the existence of the unobserved effect in the random effects model. The random effects model is only valid when the variance of the model is not zero (0). After the validity assumption of the random effects model is met, the next discretion is either to rely on the random effects model or the fixed effects model results. The decision to choose an appropriate model is based on the Hausman specification test by Hausman (1978). A significant value of chi-square in the Hausman test indicates the existence of a correlation between the composite error term and the independent variables in the model, which, in turn, favour the fixed effects model.

\section{Results}

\subsection{Descriptive Statistics}

The descriptive statistics of the dependent and independent variables are shown in Table 1. The average audit delay (DELAY) is 101 days with a standard deviation of 25 days. The length of audit report period ranges from a minimum of 20 days to a maximum of 364 days. The mean delay is lower than the minimum requirement of Bursa Malaysia of four (4) months. The average FRS 138 adoption (FRS138) is $57.9 \%$ whereas $42.1 \%$ of the sample companies do not adopt FRS 138. The mean for the log total assets (In SIZE) is 19.68 with a standard deviation of 1.32. For the ratio of total liabilities over total assets (DEBT), the mean variable is $43.54 \%$ and the standard deviation is $27.21 \%$. The average observations, which experienced losses (LOSS) in the current year is $22.87 \%$ ( $42.00 \%$ standard deviation). From 2,440 firm-year observations, the average of companies with qualified opinion (QUALIFIED) is $1.31 \%$ and the standard deviation is $11.38 \%$. The mean square root number of subsidiaries (SQSUBS) is 3.86 with a minimum of zero (0) and maximum of 17.69 . On average, $73.93 \%$ of the firm-year observations having accounting year-end between 31 December until 31 March (YEND), and 64.80\% of the observations, are audited by the Big 4 auditors (BIG4). On average, $26.72 \%$ of the observations are classified under consumer, construction and manufacturing sectors (INDUST) with a standard deviation of $44.26 \%$.

For the corporate governance variables, the mean for the proportion of independent directors on the board (BDIND) is 0.42 with a standard deviation of 0.12 . On average, $27.30 \%$ of the sample companies have CEOs who also hold the position of the chairman of the board (DUAL). The mean for shareholding held by the block shareholdings (BLOCK) is $40.13 \%$ ( $22.56 \%$ standard deviation).

\subsection{Panel Regression}

The Breush Pagan Lagrangian Multiplier test indicates that the calculated p-value is more than the tabulated value $(\mathrm{p}=0.000)$, thus, the null hypothesis is rejected. The significance of the chi-square $\left(\chi^{2}=1779.26\right)$ of the test signifies that the variance of the random effects model is not zero (0). Hence, the random effects model is more suitable than the constant variance model. Subsequently, the Hausman test is conducted in choosing the best model that suits the data. The results for Hausman test (fixed effects - random effects), as stated in Table 2(Note 3), show that $\chi^{2}=67.12$ and the p-value of the $\chi^{2}$ is 0.000 . Since the chi-square values are highly significant, the null hypothesis should be rejected, which indicates that there is a significant difference between the coefficients of the random effects and fixed effects models. Hence, it is risky to assume that there is no correlation between the error terms of the audit 
delay model and its independent variables. Thus, the stricter assumption of the random effects model cannot be used, instead, the fixed effects model supports the assumption for correlation to exist.

Table 2 depicts that the $\mathrm{R}^{2}$ for the fixed effects regression model is 0.038 indicating that $3.81 \%$ of the variation in audit delay can be explained by independent variables. The results also show that the F-value of 4.47 is highly significant ( $p$-value $=0.000$ ). This indicates that the relationship between the dependent (audit delay) and its independent variables in the fixed effects regression model is highly significant. The low adjusted $\mathrm{R}^{2}$ is due to the validity test requirement to use the fixed effects model.

From Table 2, the hypothesis variable FRS138 shows a p-value of 0.023 . With a positive coefficient of 0.016 , the hypothesis is supported at the $5 \%$ level of significance. The results suggest that the adoption of FRS 138 has significantly lengthened the audit timeliness.

\section{Discussion}

\subsection{Results of Descriptive Statistics}

The descriptive analysis revealed that the public listed companies in Malaysia completed the audit engagement and signed the auditor's report in 101 days. Compared to other countries such as Bahrain in 48 days (Al-Ajmi, 2008); India in 92 days (Almosa and Allabas, 2007); Athens in 98 days (Leventis et al., 2005); and Egypt in 67 days (Afify, 2009), the Malaysian companies reported a longer mean audit delay.

\subsection{Regression Results}

The $\mathrm{R}^{2}$ of the fixed effects model of $3.81 \%$ is highly significant in explaining the audit delay model. Since the fixed effects model eliminates time-constant variables, it is normal to obtain a low $\mathrm{R}^{2}$ as compared to the pooled OLS regression and random effects model regression. For instance, the adjusted $\mathrm{R}^{2}$ for the pooled OLS is $18.15 \%$ and the random effects model resulted in an adjusted $\mathrm{R}^{2}$ of $18.10 \%$. The result for pooled OLS is slightly higher than a study conducted by Abdullah (2007) with an adjusted $\mathrm{R}^{2}$ of $15 \%$, also using the Malaysian audit market. A low $\mathrm{R}^{2}$ is also reported by Ahmed (2003) at 1\% for Bangladesh, $7.9 \%$ for India and 23\% for Pakistan. Che-Ahmad and Abidin (2008) utilized Malaysian audit delay data, which resulted in an adjusted $\mathrm{R}^{2}$ of $19.5 \%$.

The results of this study provide support for numerous allegations that the accounting treatments for intangible assets are troublesome in the area of financial reporting. The difficulty of the standard lies in the process of identifying whether the intangibles meet the criteria of identifiable non-monetary assets. Moreover, the verdict of whether a company has control over the assets and bringing future economic benefits is also a complex procedure. The result of this study is in line with a statement by Bohusova and Svoboda (2010), who assert that recognition and measurement criteria for IFRS 138 are quite detailed and strict. The researchers further argue that the intangible assets have a very broad concept since some of the ordinary activities are also considered as intangible assets such as movies, franchises, customer lists, marketing rights and software. On the part of recognition, it is difficult to ascertain whether the intangible assets meet the criteria of recognition even though it already fulfils the definition of intangible assets and has clear future economic benefits.

Moreover, the results offer an indication that the auditors truly regard IFRS 138 as a complex and troublesome standard. The significant increase in the audit delay is a reflection of the additional efforts on the part of auditors to understand, validate and produce an audit opinion that the financial statements are free from material errors.

\subsection{Control Variable Results}

For the control variables, the results reveal that four (4) out of nine (9) variables (excluding two (2) time-invariant variables) are significantly associated with audit delay with a predicted direction. First, the size of client (InSIZE), which is measured by its total assets, is significant at the $10 \%$ level with a positive relationship, thus, implying that larger companies require more audit verification. Nevertheless, the direction is not as predicted and contradicted previous studies such as Al-Ajmi (2008) and Khasharmeh and Aljifri (2010). The client's losses in the current year (LOSS) are significant at the $1 \%$ level of significance, and positively influenced audit timeliness $(\mathrm{p}=0.000)$. The result is consistent with several past studies such as Bamber et al. (1993) and Afify (2009). The qualified opinion (QUALIFIED) is also found to be significantly related to audit delay with a positive relationship $(\mathrm{p}=0.022)$, suggesting that a client with a qualified opinion requires more time to be audited. Past literature also documented a significant positive association between audit opinion and audit delay (see for example: Jaggi and Tsui, 1999; Carslaw, Mason and Mill, 2007). Another control variable that is significantly associated with audit delay is board independence (BDIND). This variable had a positive relationship with audit delay with a p-value of 0.030 , indicating that the presence of independent management requires higher quality financial statements and a superior quality audit, thus, the auditor needs to put more effort into the verification process. The result is in line with the study conducted by Afify (2009). 


\section{Conclusion}

The main objective of this study is to examine the relationship between the adoption of one (1) of the most complex standards, namely FRS 138, and the timeliness of audit report in Malaysia. The timely issuance of audit report is an important element to judge the quality of financial reports in developing countries since investors rely on the information presented in the annual report (Leventis et al., 2005). This study is motivated from the complexity issue of IFRS 138 adoption, which might challenge the audit firms' efficacy to produce timely audit reports. Using 4-year data, the panel data regression was conducted on a sample of 2,440 firm-year observations. The validity test of the Breush Pagan LM test shows the existence of the unobserved effect in the random effects model. Nevertheless, the Hausman test signifies that a correlation exists between the error terms, hence, requiring the use of the fixed effects model. The results of the fixed effects model support the hypothesis that there is a significant increase in audit delay after the FRS 138 adoption. The findings of this study provide further support concerning the allegation that the issue on intangible assets is never-ending. Hence, it can be concluded that the adoption of FRS 138 has significantly increased the length of time required to issue an audit report and, furthermore, this study provides evidence of the complexity of the new FRS 138 in Malaysia.

All financial and non-financial data used in this study were hand collected from the annual reports of Bursa Malaysia. Simon, Teo and Trompeter (1992) believe that hand collected data from the annual reports would guarantee more accurate data and eliminate non-response bias, which normally occurs in questionnaire surveys.

\section{References}

Abdelsalam, O. H., \& Street, D. L. (2007). Corporate governance and the timeliness of corporate internet reporting by U.K. listed companies. Journal of International Accounting, Auditing and Taxation, 16, 111-130. http://dx.doi.org/10.1016/j.intaccaudtax.2007.06.001

Abdelsalam, O., \& El-Masry, A. (2008). The impact of board independence and ownership structure on the timeliness of corporate internet reporting of Irish-listed companies. Managerial Finance, 34(12), 907-918. http://dx.doi.org/10.1108/03074350810915842

Abdullah, S. N. (2007). Board composition, audit committee and timeliness of corporate financial reports in Malaysia. Corporate Ownership and Control, 4(2), 33-45.

Afify, H. A. E. (2009). Determinants of audit report lag: Does implementing corporate governance have any impact? Empirical evidence of Egypt. Journal of Applied Accounting, 10(1), 56-86.

Ahmed, K. (2003). The timeliness of corporate reporting: A comparative study of South Asia. Advances in International Accounting, 16, 17-43. http://dx.doi.org/10.1016/S0897-3660(03)16002-3

Al-Ajmi, J. (2008). Audit and reporting delays: Evidence from an emerging market. Advances in Accounting, incorporating Advances in International Accounting, 24, 217-226.

Almosa, S. A., \& Alabbas, M. (2007). Audit delay: Evidence from listed joint companies in Saudi Arabia. Paper presented at the Seminar Saudi Stock Exchange: "Future Prospective", King Khalid University.

Ashton, R. H., Graul, P. R., \& Newton, J. D. (1989). Audit delay and timeliness of corporate reporting. Contemporary Accounting Research, 5(2), 657-673. http://dx.doi.org/10.1111/j.1911-3846.1989.tb00732.x

Ashton, R. H., Willingham, J. J., \& Elliot, R. K. (1987). An empirical analysis of audit delay. Journal of Accounting Research, 25(2), 275-292. http://dx.doi.org/10.2307/2491018

Baltagi, B. (2005). Econometric analysis of panel data (Third ed.). England: John Wiley and Sons.

Bamber, E., Bamber, L., \&Schoderbek, M. (1993). Audit structure and other determinants of audit report lag. Auditing: A Journal of Practice \& Theory, 21(1), 1-23.

Bliss, M. A., Muniandy, B., \& Majid, A. (2007). Ceo duality, audit committee effectiveness and audit risks. Managerial Auditing Journal, 22(7), 13.

Bohusova, H., \& Svoboda, P. (2010). Comparability of financial statements prepared according to IFRS and IFRS for SMEs in field of intangible assets. The Business Review, Cambridge, 16(1), 239-244.

Bonsón-Ponte, E., Escobar-Rodríguez, T., \& Borrero-Domínguez, C. (2008). Empirical analysis of delays in the signing of audit reports in Spain. International Journal of Auditing, 12, 129-140. http://dx.doi.org/10.1111/j.1099-1123.2008.00375.x

Canibano, L., Garcia-Ayuso, M., \& Sanchez, P. (2000). Accounting for intangibles: A literature review. Journal of Accounting Literature, 19, 102-130. 
Carslaw, C. A. P. N., \& Kaplan, S. E. (1991). An examination of audit delay: Further evidence from New Zealand. Accounting and Business Research, 22(85), 21-32.

Carslaw, C., Mason, R., \& Mill, J. R. (2007). Audit timeliness of school district audits. Journal of Public Budgeting, Accounting and Financial Management, 19(3), 290-316.

Che-Ahmad, A., \& Adibin, S. (2008). Audit delay of listed companies: A case of Malaysia. International Business Research, 1(4), 32-39.

Chou, W. L., \& Lee, D. S. (2003). Cointegration analysis of audit pricing model: A panel unit root test approach. Journal of Business Finance and Accounting, 30(7\&8), 1141-1164. http://dx.doi.org/10.1111/1468-5957.05370

Davies, B., \& Whitted, G. P. (1980). The association between selected corporate attributes and timelines in corporate reporting: Further analysis. Abacus, 16, 48-60. http://dx.doi.org/10.1111/j.1467-6281.1980.tb00085.x

Dyer, J. C., \& McHugh, A. J. (1975).The timeliness of the Australian annual report. Journal of Accounting Research, 13(2), 204-219.

Egginton, D. A. (1990).Towards some principles for intangible asset accounting. Accounting and Business Research, 20(79), 193-205.

Ezat, A., \& El-Masry, A. (2008). The impact of corporate governance on the timeliness of corporate internet reporting by Egyptian listed companies. Managerial Finance, 34(12), 848-867.

Gallego, I., \& Rodriguez, L. (2005). Situation of intangible assets in Spanish firms: An empirical analysis. Journal of Intellectual Capital, 6(1), 105-126. http://dx.doi.org/10.1108/14691930510574690

Givoly, D., \& Palmon, D. (1982). Timeliness of annual earnings announcement: Some empirical evidence. The Accounting Review, 3, 486 - 508.

Grasenik, K., \& Low, J. (2004). Shaken, not stirred: Defining and connecting indicators for the measurement and valuation of intangibles. Journal of Intellectual Capital, 5(3), 268-281. http://dx.doi.org/10.1108/14691930410533696

Hausman, J. A. (1978). Specification test in econometrics. Econometrica, 46(6), 1251-1271. http://dx.doi.org/10.2307/1913827

Healy, P. M., Myers, S. C., \& Howe, C. D. (2002). R\&D Accounting and the tradeoff between relevance and objectivity. Journal of Accounting Research, 40(3), 677-710. http://dx.doi.org/10.1111/1475-679X.00067

Hendriksen, E. S., \& Van Breda, M. F. (1992). Accounting Theory (Fifth ed.): Burr Ridge: Irwin.

Hoogendoorn, M. (2006). International accounting regulation and IFRS implementation in Europe and beyond-experiences with first-time adoption in Europe. Accounting in Europe, 3, 23-26. http://dx.doi.org/10.1080/09638180600920087

Iman, S., Ahmed, Z. U., \& Khan, S. H. (2001). Association of audit delay and audit firms' international links: Evidence from Bangladesh. Managerial Auditing Journal, 16(3), 129-133. http://dx.doi.org/10.1108/02686900110385669

Jaggi, B., \& Tsui, J. (1999). Determinants of audit report lag: Further evidence from Hong Kong. Accounting and Business Research, 30(1), 17-28.

Kaufmann, L., \& Schneider, Y. (2004). Intangibles: A synthesis of current research. Journal of Intellectual Capital, 5(5), 366-388. http://dx.doi.org/10.1108/14691930410550354

Khasharmeh, H. A., \& Aljifri, K. (2010). The timeliness of annual reports in Bahrain and the United Arab Emirates: An empirical comparative study. The International Journal of Business and Finance Research, 4(1), 51-71.

Knechel, W. R., \& Payne, J. L. (2001).Additional evidence on audit report lag. Auditing: A Journal of Practice \& Theory, 20(1), 137-146. http://dx.doi.org/10.2308/aud.2001.20.1.137

Lawrence, J. E., \& Glover, H. D. (1998). The effect of audit firm mergers on audit delay. Journal of Management Issues, 10(2), 151-164.

Lev, B., \& Zarowin, P. (1999).The boundaries of financial reporting and how to extend them. Journal of Accounting Research, 37(2), 353-385. http://dx.doi.org/10.2307/2491413

Leventis, S., Weetman, P., \& Caramanis, C. (2005). Determinants of audit report lag: Some evidence from the Athens Stock Exchange. International Journal of Auditing, 9, 45-58. http://dx.doi.org/10.1111/j.1099-1123.2005.00101.x 
Lhaopadchan, S. (2010).Fair value accounting and intangible assets. Journal of Financial Regulation and Compliance, 18(2), 120-130. http://dx.doi.org/10.1108/13581981011033989

Newton, J. D., \& Aston, R. H. (1989). The association between audit technology and audit delay. The association between audit technology and audit delay, 8, 22-37.

Owusu-Ansah, S. (2000). Timeliness of corporate financial reporting in emerging capital markets: Empirical evidence from the Zimbabwe stock exchange Accounting and Business Research, 30(3), 241-254. http://dx.doi.org/10.2139/ssrn.215929

Payne, J. L., \& Jensen, K. L. (2002). An examination of municipal audit delay. Journal of Accounting and Public Policy, 21, 1-29. http://dx.doi.org/10.1016/S0278-4254(02)00035-2

Schadewitz, H., \& Vieru, M. (2010). Impact of IFRS transition complexity on audit and non-audit fees: Evidence from small and medium-sized listed companies in Finland. LiiketaloudellinenAikakauskirja, 1, 11-41.

Simon, D. T., Teo, S., \& Trompeter, G. (1992). A comparative study of the market for audit services in Hong Kong, Malaysia and Singapore. The International Journal of Accounting, 27, 234-240.

Soltani, B. (2002). Timelines of corporate and audit reports: Some empirical evidence in the French context. The International Journal of Accounting, 37, 215-246. http://dx.doi.org/10.1016/S0020-7063(02)00152-8

Tollington, T. (2008). The cognitive assumptions underpinning the accounting recognition of assets. Management Decision, 38(1/2), 89-98. http://dx.doi.org/10.1108/00251740010317441 .

Wang, X., Gu, J., \& Chen, W. (2008). Timeliness of annual reports, management disclosure and information transparency: Evidence from China [Electronic Version], from ssrn.com/abstract=1143213.

Whittred, G. P. (1980). Audit qualification and the timeliness of corporate annual reports. The Accounting Review, 55(4), 563-577.

\section{Notes}

Note 1. IFRS in Malaysia is branded as Financial Reporting Standards (FRS). The number assigned has been renumbered to match the IFRS. For instance, MASB 1 Presentation of Financial Statements is numbered as FRS 101, IFRS 1 is known as FRS 1,IFRS 138 is FRS 138 and so forth.

Note 2. In this study, FRS 138 is used interchangeably with IFRS 138.

Note 3. Based on the modified Wald's test for groupwise heteroscedasticity statistic results, the audit delay resulted in $\chi^{2}(610)=1.1 \mathrm{e}+07$, significant at 0.01 level. Thus, the findings indicate the presence of heteroscedasticity. The heteroscedasticity problem is corrected by obtaining the White Heteroscedasticity-corrected standard error or robust standard error. Thus, the panel regression results of this study are derived based on robust standard errors. There is no multicollinearity problem since the Variance in Factor (VIF) for all variables are less than 2.0. The correlation and autocorrelation problem are encountered when fixed effects regression is used.

Table 1. Descriptive Statistics of Regression Variables for the Audit Delay Model $(n=2,440)$

\begin{tabular}{|l|c|c|c|c|}
\hline \multicolumn{1}{|c|}{ Variables } & Mean & Minimum & Maximum & $\begin{array}{c}\text { Standard } \\
\text { Deviation }\end{array}$ \\
\hline DELAY & 100.663 & 20 & 364 & 25.208 \\
\hline FRS138 & 0.579 & 0 & 1 & 0.494 \\
\hline InSIZE & 19.683 & 15.78 & 26.39 & 1.317 \\
\hline DEBT & 0.435 & 0.0004 & 15.091 & 0.272 \\
\hline LOSS & 0.229 & 0 & 1 & 0.420 \\
\hline QUALIFIED & 0.013 & 0 & 1 & 0.114 \\
\hline SQSUBS & 3.861 & 0 & 17.69 & 2.086 \\
\hline YEND & 0.739 & 0 & 1 & 0.439 \\
\hline BIG4 & 0.648 & 0 & 1 & 0.478 \\
\hline INDUST & 0.267 & 0 & 1 & 0.443 \\
\hline BDIND & 0.421 & 0 & 2.7 & 0.120 \\
\hline DUAL & 0.273 & 0 & 1 & 0.446 \\
\hline BLOCK & 0.401 & 0 & 0.998 & 0.226 \\
\hline
\end{tabular}


Table 2. Fixed Effects Regression Results for Audit Delay $(n=2,440)$

\begin{tabular}{|c|c|c|c|c|c|}
\hline \multicolumn{6}{|c|}{$\begin{array}{l}\operatorname{lnDELAY}_{\mathrm{it}}=\alpha+\beta_{1} \text { FRS138 }_{\mathrm{it}}+\beta_{2} \operatorname{lnSIZE}_{\mathrm{it}}+\beta_{3} \text { DEBT }_{\mathrm{it}}+\beta_{4} \text { LOSS }_{\mathrm{it}}+\beta_{5} \text { QUALIFIED }_{\mathrm{it}}+\beta_{6} \text { SQSUBS }_{\mathrm{it}}+ \\
\beta_{7} \mathrm{YEND}_{\mathrm{it}}+\beta_{8} \mathrm{BIG}_{\mathrm{it}}+\beta_{9} \text { INDUST }_{\mathrm{it}}+\beta_{10} \text { BDIND }_{\mathrm{it}}+\beta_{11} \text { DUAL }_{\mathrm{it}}+\beta_{12} \text { BLOCK }_{\mathrm{it}}+\mathrm{a}_{\mathrm{i}}+\mathrm{u}_{\mathrm{it}}\end{array}$} \\
\hline Variables & & $\begin{array}{l}\text { Expected } \\
\text { Sign }\end{array}$ & $\beta$ & t-value & *p-value \\
\hline Constant & & & 3.884 & 12.80 & 0.000 \\
\hline FRS138 & & + & 0.016 & 2.28 & 0.023 \\
\hline $\operatorname{lnSIZE}$ & & - & 0.030 & 1.89 & 0.059 \\
\hline DEBT & & + & 0.033 & 0.89 & 0.374 \\
\hline LOSS & & + & 0.043 & 3.55 & 0.000 \\
\hline QUALIFIED & & + & 0.130 & 2.30 & 0.022 \\
\hline SQSUBS & & + & 0.013 & 1.60 & 0.110 \\
\hline YEND & & + & - & - & - \\
\hline BIG4 & & - & -0.013 & -0.69 & 0.489 \\
\hline INDUST & & + & - & - & - \\
\hline BDIND & & - & 0.103 & 2.18 & 0.030 \\
\hline DUAL & & $?$ & -0.003 & 0.12 & 0.904 \\
\hline BLOCK & & - & -0.000 & -0.38 & 0.702 \\
\hline F Ratio & 4.47 & & & & \\
\hline Significant & 0.000 & & & & \\
\hline R Square & 0.038 & & & & \\
\hline Hausman Test $\mathrm{Chi}^{2}$ & 67.12 & & & & \\
\hline Significant of Hausman Test & 0.000 & & & & \\
\hline
\end{tabular}

*p-value represents one-tail tests when the direction of the coefficient is consistent with expectations 